Інноватика у вихованні. Випуск 12. 2020.

УДК 37(091)(477)

DOI: $10.35619 /$ iiu.v1i12.318

Баліка Людмила

кандидат педагогічних наук, доцент, доцент кафедри теорії і методики виховання Рівненського державного гуманітарного університету,

м. Рівне, Україна

ORCID: 0000-0003-0042-7744

e-mail: liudmyla.balika@rshu.edu.ua

Ярута Ніна вихователь-методист ЗДО № 33 м. Рівне, м. Рівне, Україна ORCID: 0000-0003-2705-5725 e-mail: yaruta.nina@gmail.com

\title{
ФОРМУВАННЯ ЦІННІСНИХ ОРІЕНТАЦІЙ ДІТЕЙ ДОШКІЛЬНОГО ВІКУ НА ОСНОВІ ПЕДАГОГІЧНОӤ СПАДЩИНИ В. О. СУХОМЛИНСЬКОГО: 3 ДОСВІДУ РОБОТИ
}

\begin{abstract}
Анотація. У статті обгрунтована важливість формування ціннісних орієнтацій у дітей дошкільного віку на основі використання педагогічної спадщини В. О. Сухомлинського. Зосереджено увагу на тому, що головним завданням для кожного закладу дошкільної освіти є створення найкращих умов для розвитку особистості дитини: морального, інтелектуального, трудового, естетичного й ін. Проаналізовано досвід роботи вихователя-методиста ЗДО № 33 м. Рівне Н. Ярути, яка творчо використовує спадщину В. О. Сухомлинського у вихованні дітей дошкільного віку. Визначено провідну ідею діяльності вихователя-методиста - оптимізація морального досвіду дитини в умовах закладу дошкільної освіти, забезпечення взаємозв'язку моральних знань та уявлень, що діти отримують на заняттях, 3 їх застосуванням в повсякденному житі.

3'ясовано, що формування ціннісних орієнтацій дошкільників здійснюється нею через формування ціннісного ставлення до природи, життя, рукотворного світу, людини. Вихователь-методист використовує заняття, гуртки, екскурсії, спостереження, години дозвілля, акції милосердя, працю, родинні свята, бесіди та ігри у формуванні ціннісних орієнтацій дітей дошкільного віку. Особливо ефективними є: цикл занять «Дитина в природному довкіллі», «Скринька добрих справ», «Галерея духовності», робота з батьками, консультації колег й тощо.

Акцентовано увагу на тому, що працюючи з текстами казок, оповідань В. Сухомлинського, діти стають більш соціальними, емоційнішими. Зроблено висновок, що Н. О.Ярута переосмислює зміст та розробляє нові підходи формування ціннісних орієнтацій: через «прожиття» $\mathrm{i}$ переживання творів В. О. Сухомлинського, допомагає дітям відкрити світ людських взаємин, формуючи в них позитивне сприйняття довкілля і себе у ньому; підводить дітей до особистісного сприйняття і розуміння таких філософських понять, як душа, совість, добро, щастя.
\end{abstract}


Ключові слова: ціннісні орієнтації, діти дошкільного віку, творча спадщина, В. О. Сухомлинський, заклад дошкільної освіти.

Постановка проблеми. У сучасному освітньому просторі спостерігається пріоритет навчання над вихованням, проблема засвоєння моральних норм i цінностей, що закладаються впродовж дошкільного віку, відходить на другий план порівняно 3 увагою до інтелектуального розвитку дітей. Це 3 часом призводить до значних психологічних проблем та порушень у розвитку кожної окремої особистості і до деградації суспільства в цілому. Саме тому особливої актуальності в наш час набуває вивчення та закладення у свідомості дорослих ціннісних орієнтацій розвитку сучасної дитини-дошкільника. В період трансформації суспільства та кризових явищ в різних сферах суспільного буття розробка цієї проблеми набуває особливої актуальності.

Дошкільний вік - період, коли дитина починає пізнавати навколишній світ, соціалізується до життя в суспільстві, прилучається до цінностей мистецтва, краси природи, людських взаємин, вчиться радіти, співпереживати, співчувати, творити добро, отримувати задоволення від пізнання світу. У Законі України «Про дошкільну освіту» зазначено, що метою освіти є забезпечення різнобічного розвитку дитини дошкільного віку відповідно до ії задатків, нахилів, здібностей, індивідуальних, психічних та фізичних особливостей та культурних потреб (Міністерство освіти і науки України, 2001).

Видатний український педагог В. Сухомлинський обгрунтував сутність моральних та духовних цінностей як ідеалів людини, коли закладаються основи добрих почуттів: людяності, доброти, доброзичливості, совісті та милосердя (Сухомлинський, 1977а). Він вважав, що «азбучна істина виховання» полягає у тому, щоб «утвердити в кожній дитині доброту, сердечність, чуйність до всього живого й красивого... Справжнє виховання полягає у тому, щоб моральний ідеал добра, правди, честі, духовної краси жив у кожному юному серці, утверджувався в активній діяльності як невід'ємна частина власного єства, власної думки, почуттів, намірів» (Сухомлинський, 1977 b).

Василь Олександрович не лише обгрунтував необхідність гуманізації навчально-виховного процесу, але й реалізував цю парадигму в практичній діяльності. Тому творче впровадження ідей педагога стосовно гуманного особистісно-орієнтованого виховання, формування у дитини дошкільного віку моральних норм, ціннісних орієнтацій, набуття нею життєвого соціального досвіду вважаємо на часі у період глибинних суспільних трансформацій.

Аналіз останніх досліджень з проблеми. Значний внесок у дослідження проблеми розвитку дітей дошкільного віку зробили сучасні науковці Н. Гавриш, В. Моляко, Т. Піроженко, Н. Портницька, О. Трусова, Р. Чумічева та ін.

Узагальнення досвіду втілення ідей педагога в сучасних закладах освіти здійснили Л. Стахів та С. Плахова (Стахів та Плахова 2010); регіональні особливості впровадження педагогічної спадщини Василя Сухомлинського схарактеризували Н. Калініченко, П. Олешко (Калініченко, 2013; Олешко, 2015). Питання наступності в роботі закладу дошкільної освіти та початкової школи шляхом впровадження в практику роботи творчої спадщини В. О. Сухомлинського вивчала Н. Бабіч (Бабіч, 2014).

Метою статті $є$ аналіз досвіду вихователя-методиста Н. Ярути ЗДО №33 $\begin{array}{lllll}\text { м. Рівне } 3 \text { упровадження творчої спадщини } & \text { В. О. Сухомлинського задля }\end{array}$ формування ціннісних орієнтирів дошкільників. 
Виклад основного матеріалу дослідження. Спадщина В. Сухомлинського дуже багатогранна, однак в центрі його уваги - особистість дитини, іiї духовний світ та моральні цінності. Педагог вважав, що центром освітнього процесу $є$ особистість дитини, тому головним завданням для кожного закладу освіти $є$ створення найкращих умов для розвитку особистості дитини: морального, інтелектуального, трудового, естетичного й ін.

Основу виховання, на переконання Василя Олександровича, мають становити загальнолюдські цінності - добро, совість, честь, обов'язок, гідність, моральність. Водночас засвоєння моральних цінностей найкраще відбувається на рівні особистісного поведінкового досвіду дитини. У книзі «Серце віддаю дітям» він писав: «Дитячий світ - це особливий світ. Діти живуть своїми уявленнями про добро й зло, честь i безчестя, людську гідність» (Сухомлинський, 1977a, с. 29).

Педагогічна спадщина В. Сухомлинського не втратила значущості для сучасної педагогічної науки і практики. Творчі досягнення видатного педагога ефективно використовуються педагогами в різних закладах освіти. Розроблена ним педагогічна система не тільки збагатила педагогічну науку новаторськими ідеями і положеннями, але й стала потужним внеском як у теорію, так і в практику освіти і виховання.

На теренах Рівненщини у багатьох закладах освіти творчо впроваджується спадщина В. Сухомлинського. Активним формуванням ціннісних орієнтацій дошкільнят на основі творчого використання досвіду Василя Олександровича Сухомлинського займається Н. Ярута - вихователь-методист ЗДО № 33 м. Рівне.

У своїй педагогічній діяльності Н. Ярута одним 3 найважливіших завдань своєї діяльності вважає забезпечення належного психолого-педагогічного супроводу процесу становлення ціннісних орієнтирів дитини в умовах дошкільного закладу.

Важливими завданнями діяльності педагога є:

1. Створення позитивної мотивації навчання. Основним джерелом мотивації є потреба та інтереси самих дітей. Спираючись на них, педагог може обирати конкретні методи та моделювати особисту поведінку дітей. Позитивне налаштування на заняття значною мірою залежить від творчо спланованої та доведеної до дітей мети: «Що і як ми будемо вивчати на цьому занятті? Яким чином можуть бути використані знання та вміння, отримані на занятті?».

2. Збереження сприятливого мікроклімату та психологічного комфорту. Активізація навчання потребує створення атмосфери відповідальної та відвертої взаємодії, використання засобів комунікації для заохочення дітей, інтерактивних вправ, що дають змогу визначити власну позицію та співпрацювати $з$ іншими. Особливого значення у зв'язку 3 цим набуває гуманізація спілкування, міжособистісних стосунків, позитивний, емоційний стан дітей, створення ситуації успіху.

3. Формування у дитини бажання і уміння вчитися. Зростає питома вага особистісно орієнтованих технологій, які забезпечують розвиток і саморозвиток дитини, грунтуючись на виявлених індивідуальних особливостях іiі як суб'єкта пізнання; дають змогу кожній дитині 3 урахуванням іiі здібностей, нахилів, інтересів реалізувати себе у навчальній діяльності; створюють необхідні умови для самореалізації особистості. Саме на таких засадах побудовані сучасні інноваційні педагогічні технології: інформаційні, проєктні, комунікативні, розвивальне навчання тощо, які забезпечують інтенсифікацію навчальної 
діяльності, підвищення рівня мотивації навчання, формування і розвиток творчої особистості дитини.

4. Використання активних методів навчання. Сьогодні педагогічні інновації пов'язані із застосуванням інтерактивних методів у професійній діяльності педагога. Вони передбачають активну взаємодію всіх дітей у процесі бесіди, діалогу, дискусії, роботи в малих групах, парах, мікроколективах, де відбувається розподіл ролей, чітке виконання обов'язків кожним, обмін інформацією і накопичення позитивного досвіду. За таких умов освітньовиховний процес повинен орієнтуватися не лише на засвоєння дітьми чужого досвіду, а й на формування власних стратегій, самонавчання, самовиховання й саморозвитку (Ярута, 2018).

Для Ніни Олексіївни виховання всебічно розвиненої особистості - це виховання, в якому поєднуються моральна, ідейна, громадянська, розумова, творча, трудова, естетична, емоційна й фізична грані досконалості, які визначені у Базовому компоненті дошкільної освіти і визначають вимоги суспільства та держави до вихованості, обізнаності й навченості дошкільника, а також умови, за яких вони можуть бути досягнуті. У своїй діяльності Н. Ярута систематизує матеріал та впроваджує в освітній процес найефективніші форми та методи, які допоможуть розв'язати проблему формування ціннісних орієнтирів дошкільників через призму творчої спадщини В. О. Сухомлинського. Ефективним для формування ціннісних орієнтирів дітей дошкільного віку $є$ змістовне життя малюків у закладі дошкільної освіти: цікаві заняття, гуртки, екскурсії, різноманітні спостереження, години дозвілля, акції милосердя, праця, яскраві родинні свята, бесіди та ігри.

Процес активного привласнення ціннісних орієнтацій людства є природним для дошкільного дитинства. Та для його розгортання необхідні допоміжні «культурні засоби». Тому, провідна ідея досвіду вихователя-методиста полягає у оптимізації морального досвіду дитини в умовах закладу дошкільної освіти, забезпечення взаємозв'язку моральних знань та уявлень, що діти отримують на заняттях, 3 їх застосуванням в повсякденному житі. Щоденна систематична i планомірна робота спрямована на створення умов, за яких дитина має можливість прожити знайомі морально-етичні правила, які стають частиною іiі життя, що забезпечить досягнення високих результатів у роботі з формування ціннісних орієнтирів.

Складовими ціннісних орієнтацій є ціннісне ставлення до природи, життя, що інтегрує в собі такі утворення, як: визнання права на життя кожної істоти; бережне ставлення до будь-яких проявів життя; сприймання життя в усій його різноманітності, усіх його проявах і формах; рукотворного світу - розуміння того, що предмети створені завдяки праці людини, до них слід бережливо ставитися, розуміння їх корисності в житті людини, отримання насолоди від сприймання рукотворного світу; людини - прийняття людини як цінності, повага до ії автономії, самопочуття, інтересів

В. Сухомлинський визначав природу як провідний чинник виховання. Приміром, у статті «Школа і природа» він писав: «багаторічний досвід навчально-виховної роботи переконує, що природа не тільки об'єкт пізнання, не тільки сфера активної діяльності вихованців, а й частина їх буття, взаємовідносин, всього ладу їх життя» (Сухомлинський, 1977, с. 536). На думку Н. О. Ярути, природа сама собою не виховує. Дитина стає розумною, моральною, прекрасною, доброю і непримиримою до зла за умови активної 
взаємодії з природою. Тому на заняттях «Повітря - це моє здоров'я і життя планети», «Краплинка сестриця - мандрівниця» використовувалися оповідання В. Сухомлинського «П'ять дубків» і «Краплинка роси» та ін., які привернули увагу дітей до проблем забруднення навколишнього середовища та необхідності його охорони. Такі практичні дії, як висівання насіння, колективне прибирання території, моделюють правила поведінки дітей у природі в конкретних життєвих ситуаціях.

Ніна Олексіївна переконана що, наслідуючи прийоми і методи виховання видатного педагога, потрібно брати дітей за руку і вести їх в рідне довкілля спостерігати, думати, мислити, заохочувати. Розроблений нею цикл занять «Дитина в природному довкіллі» допомагає виховательці прищепити любов до природи (в кожному куточку вчить залишити серця частинку). Діти не тільки спостерігають, думають, вони шукають відповіді серед природи на численні «чому?». Такі заняття залишають у кожної дитини іскру любові до природи (Ярута, 2018, с. 9).

У формуванні ціннісних орієнтирів дошкільників одне із провідних місць належить праці. Адже під час праці формуються моральні, інтелектуальні, емоційні та вольові якості особистості. Н.Ярута розділяє думку В. Сухомлинського, що важливим елементом духовного життя дитини $\epsilon$ ставлення до праці. Вихователь-методист переконана, що дошкільнята повинні змалечку залучатися до праці, та відчувати радість від неї, навчитися змалечку узгоджувати власні бажання з інтересами однолітків та дорослих, а це важливо для виховання доброти й людяності, самодисципліни, без якої немає совісті, немає справжньої людини. У ЗДО дошкільнята доглядають за квітами, акваріумом, працюють 3 вихователем на квітниках. Під час роботи діти ознайомлюються 3 правилами безпеки і культури праці, особистої гігієни в процесі виконання трудових доручень, охорони навколишнього середовища, 3 правилами поведінки в природі.

Чільне місце відведене слуханням та обговоренню оповідань i казок В. О. Сухомлинського. На занятті «Добре тому жити, хто добро вміє робити», яке проводилося в комплексі з малюванням, щоб діти змогли передати почуте, побачене, відчуте на аркуші паперу і «вкласти» в малюнок усі свої емоції та відчуття, обрати відповідні кольори, що характеризують настрій. В. Сухомлинський зазначав, що: «діти не просто переносять на папір щось із навколишнього світу, а живуть у цьому світі, входять у нього, як творці краси, дістаючи насолоду від неї» (Сухомлинський, 1977d). Такі заняття допомагають розвивати у дітей уяву, увагу, різні види пам'яті. Під час занять важливо, щоб дитина могла висловити свою думку, підкреслити позитивні або негативні риси персонажів твору. Для закріплення матеріалу, з яким ознайомились діти в групі, вихователь пропонує дошкільнятам виконати вдома 3 батьками таке творче завдання - намалювати, зробити аплікацію за змістом твору, що сподобався або запам'ятався дітям.

Вивчаючи 3 дітьми різні теми соціального спрямування, Н. Ярута використовує твори В.О.Сухомлинського, які дають можливість глибше зануритись у їх суть. Наприклад, опрацьовуючи тему «Моя сім'я», Ніна Олексіївна організовує розповіді дітей про всіх членів родини, про ставлення одне до одного в родині; про приклади піклування одне про одного. На допомогу в організації таких розповідей вихователька використовує твори Василя Олександровича: «Сьома дочка» - виховання любові до матері не тільки 
на словах, а й ділом добрим; «Чому дідусь такий добрий сьогодні» - емоційний стан онука, його вболівання за свого дідуся, за його самопочуття. Піднімаючи проблеми бережливого ставлення до іграшок, використовує твір «Люлька під дощем», який викликає співчуття до дівчинки, радість за їі хоробрість, навіть заради іграшки. Також цей твір допомагає виховувати у дітей співчуття до ближнього, слабкого; бажання допомагати комусь у біді.

У своїй роботі вихователь-методист Н. Ярута підтримує тісний зв'язок із батьками своїх вихованців. Проведення родинних свят $є$ невід’ємною частиною співпраці вихователя, дітей та батьків. До організації та проведення всіх дитячих свят залучаються батьки, які беруть активну участь і у їх підготовці та у їх проведенні. Наприклад, пережиті душевні емоції під час створення танцю «Мамині руки наймиліші» спонукає відчути духовну, нерозривну любов матері та дитини.

3 метою ознайомлення батьків 3 літературною спадщиною В. О. Сухомлинського педагог рекомендує їм книги: «Квітка сонця», «Всі добрі люди - одна сім'я», «Я розповім вам казку», «Школа під голубим небом», «Бджолина музика» для читання вдома. Зміст художніх творів-мініатюр сприяє зародженню у дитячих душах високих моральних, гуманістичних почуттів любові до своїх батьків, рідних, поваги до людей похилого віку, милосердя до немічних і нещасних.

Вихователькою створено куточок «Скринька добрих справ» - окремо відведене місце в груповій кімнаті, де розміщуються сюжетні картинки, що демонструють різні моральні ситуації. Це місце використовується для самостійних відвідувань дітьми та для індивідуального розмірковування i мимовільного запам'ятовування позитивних вчинків. Одні i ті самі картинки доцільно розглядати з різних аспектів, залежно від теми заняття: «Чи бачите на картинках дітей із хорошим настроєм? Поясніть причину такого настрою» (аналогічне запитання про сумний настрій), «Чи бачите на картинах дітей чуйних, уважних? Чи бачите ви на картинах хороші вчинки?» тощо. Галерея мобільна, картина час від часу змінюється.

Також вихователькою оформлена «Галерея духовності», невід’ємним атрибутом якої є інформаційний блок для педагогів, батьків і дітей, розміщений в зручному місці і складається 3 шести секторів, які мають визначені теми: норми моральності за педагогічною спадщиною В. Сухомлинського (зібрані матеріали теоретичного та практичного змісту, що розкривають основні моральні цінності, орієнтири, переконання дошкільників на основі педагогічної спадщини В. Сухомлинського); духовні цінності сім’ї та родини; моральні основи християнства; до витоків народної культури; прикладне мистецтво у формуванні загальнолюдських цінностей; взаємодія дошкільного закладу і сім'ї (Ярута, 2018).

Основними формами та видами роботи виховательки 3 «Галереєю духовності» були: бесіди-роздуми, бесіди-обговорення, читання художніх творів духовно-морального змісту, моделювання життєвих ситуацій, що вимагають морального вибору, зустрічі з цікавими людьми тощо. Крім макетів, предметів, експонатів до творів В. Сухомлинського «Галерея духовності» надзвичайно багата прикладами народної творчості: казки і легенди, пісні і думи, загадки, прислів'я i приказки, веселі забавлянки та ніжні колискові, цікаві ігри, мирилочки-дражнилочки. 
Вихователька переконана, що атмосфера, в якій живе дитина, повинна бути просякнута доброзичливістю, любов'ю, гуманністю. Оточуюча дитину атмосфера стає тоді засобом виховання почуттів, уявлень, поведінки, тобто активізує весь механізм морального виховання і впливає на формування певних моральних якостей й ціннісних орієнтацій.

Н. О. Ярута систематично проводить консультації як для батьків («Правове виховання 3 використанням творів В. О. Сухомлинського», «Батьківська педагогіка - енциклопедія сімейного виховання», «Роль сім’ї у виховній системі В. О. Сухомлинського»), так і для вихователів («Система виховання дитини дошкільного віку за В. О. Сухомлинським», «Трудове виховання дітей старшого віку», «Розвиток пізнавальної діяльності дитини в освітньому процесі»). Такі консультації допомагають розкрити основні ідеї В. О. Сухомлинського та залучити як батьків, так і колег-вихователів до впровадження ідей педагога в практику виховання дітей.

Висновки і перспективи подальших розвідок. Аналіз досвіду вихователяметодиста Н. О.Ярути 3 творчого впровадження спадщини В. О. Сухомлинського дає змогу стверджувати, що Н. О. Ярута створила своєрідну авторську систему 3 формування ціннісних орієнтацій дітей дошкільного віку. Використання оповідань і казок педагога допомагає вчити дітей бачити, а не просто дивитися; чути, а не просто слухати відчувати, не просто спостерігати; доторкнутись до природи серцем. Слухаючи, роздумуючи над текстами казок, оповідань В. Сухомлинського, діти стають більш соціалізованими, емоційнішими, в них з'являється бажання реалізувати почерпнуті, схожі, можливо, подібні життєві ситуації в їх реальному повсякденні: у дитячому садку, вдома. Аналіз діяльності виховательки 3 формування ціннісних орієнтацій у дошкільників засвідчив, що використання нею педагогічної спадщини В. Сухомлинського позитивно впливає на формування духовно-морального світогляду дітей, а також впливає на рівень їх знань, а відтак, допомагає сформувати позитивне, оптимістичне світобачення. Діти визначають свою провину, вміють поступатися власним інтересам заради загального благополуччя; уміють 3 повагою ставитися до рідних, знайомих, чужих літніх людей; зважають на думку інших, розрізняють гумор і образу.

Отже, у своїй діяльності вихователь-методист Н. О. Ярута переосмислює зміст та розробляє нові підходи до формування ціннісних орієнтирів особистості через «прожиття» і переживання творів В. О. Сухомлинського, які сповнені людяності та життєвої мудрості, допомогти дітям відкрити світ людських взаємин, формуючи у малят позитивне сприйняття довкілля i себе у ньому; підвести дітей до сприйняття і розуміння таких філософських понять, як душа, совість, добро, щастя.

Перспективи подальших наукових досліджень вбачаємо у дослідженні проблеми психолого-педагогічного супроводу в процесі формування ціннісних орієнтацій дошкільників, зокрема впливу особистості педагога на підтримку, сприяння і розвиток дитини дошкільного віку.

\section{СПИСОК ВИКОРИСТАНИХ ДЖЕРЕЛ}

Міністерство освіти і науки України, (2001) Закон України «Про дошкільну освіту». URL: https://zakon.rada.gov.ua/laws/show/2628-14.(дата звернення 26. 09. 2020) 
Сухомлинський, В. (1977 а). Серце віддаю дітям. Вибрані твори в 5-ти m. T.3. C. 7-282.

Сухомлинський, В. (1961b). Виховання моральних стимулів до пращі у молодого покоління. Київ: Знання. 44c.

Стахів, Л. та Плахова, С. (2010). Втілення ідей В. О. Сухомлинського в сучасній загальноосвітній школі. Молодь і ринок. №5 (64), с. 117-122.

Калініченко Н. (2013). Вплив $\quad$ В. О. Сухомлинського на формування освітнього середовища (70-80-ті роки XX століття). Наукові записки. Серія: Педагогічні науки. Випуск 123(I), с. 50-56.

Олешко, П. (2015). Педагогічна спадщина Василя Сухомлинського в освітньому просторі Волині. Педагогічний альманах. Випуск 26, сс.291-298.

Бабач, Н. (2014). Використання спадщини В. О. Сухомлинського у вирішенні проблеми наступності між дошкіллям та початковою школою. URL : https://dnz.ucoz.net/blog/babich_n_vikoristannja_spadshhini_v_o_sukhomlinskogo_u _virishenni_problemi_nastupnosti_mizh_doshkilljam_ta_pochatkovoju_shkoloju/2014 -02-03-14. (дата звернення 28.09. 2020).

Ярута, Н. (2018). Формування у дошкільників иілісної картини світу через призму літературної спадщини В. О. Сухомлинського. Рівне. 165 с.

Сухомлинський, В. $(1977$ с). Школа і природа. Вибрані твори в 5-ти т. Т.5. C. 536-550.

Сухомлинський, В. (1977 d). Кожна дитина - художник. Вибрані тв. у 5 m. Київ: «Радянська школа». Т. 3. С. 53-55.

\section{REFERENCES}

Ministerstvo osvity i nauky Ukrainy, (2001) Zakon Ukrainy «Pro doshkilnu osvitu» [The Law of Ukraine "On preschool education"]. URL: https://zakon.rada.gov.ua/laws/show/2628-14.(data zvernennia 26. 09. 2020). [in Ukrainian]

Sukhomlynskyi, V. (1977 a). Sertse viddaiu ditiam [I give my heart to children .. Vybrani tvory $v$ 5-ty $t$. T.3. S. 7-282. [in Ukrainian]

Sukhomlynskyi, V. (1961 b). Vykhovannia moralnykh stymuliv do pratsi $u$ molodoho pokolinnia. [Formation of moral incentives to work in the younger generation]. Kyiv: Znannia. 44 s. [in Ukrainian]

Stakhiv, L. ta Plakhova, S. (2010). Vtilennia idei V. O. Sukhomlynskoho v suchasnii zahalnoosvitnii shkoli. [Implementation of VO Sukhomlinsky's ideas in a modern secondary school]. Molod i rynok. No5 (64), s. 117-122. [in Ukrainian]

Kalinichenko N. (2013). Vplyv V. O. Sukhomlynskoho na formuvannia osvitnoho seredovyshcha (70-80-ti roky XX stolittia) [Influence of V.O. Sukhomlynskyi on the formation of the educational environment (70-80-s of the 20th century)]. Naukovi zapysky. Seriia: Pedahohichni nauky. Vypusk 123(I), s. 50-56. [in Ukrainian]

Oleshko, P. (2015). Pedahohichna spadshchyna Vasylia Sukhomlynskoho v osvitnomu prostori Volyni[Pedagogical heritage of Vasyl Sukhomlynskyi in the educational space of Volyn]. Pedahohichnyi almanakh. Vypusk 26, ss.291-298. [in Ukrainian]

Babach, N. (2014). Vykorystannia spadshchyny V. O. Sukhomlynskoho u vyrishenni problemy nastupnosti mizh doshkilliam ta pochatkovoiu shkoloiu. [Using V.A. Sukhomlynskyi heritage in solving the problem of continuity between preschool and primary school]. URL: https://dnz.ucoz.net/blog/babich_n_vikoristannja_spadshhini_v_o_sukhomlinskogo_u 
_virishenni_problemi_nastupnosti_mizh_doshkilljam_ta_pochatkovoju_shkoloju/2014 -02-03-14. (data zvernennia 28.09. 2020). [in Ukrainian]

Yaruta, N. (2018). Formuvannia u doshkilnykiv tsilisnoi kartyny svitu cherez pryzmu literaturnoi spadshchyny $V$. O. Sukhomlynskoho. [Formation of a holistic picture of the world in preschoolers through the prism of V.O. Sukhomlynskyi's literary heritage]. Rivne. 165s. [in Ukrainian]

Sukhomlynskyi, V. (1977 c). Shkola i pryroda[School and nature]. Vybrani tvory $v$ 5-ty $t$. T.5. S. 536-550. [in Ukrainian]

Sukhomlynskyi, V. (1977 d). Kozhna dytyna - khudozhnyk. [Every child is an artist ]. Vybrani tv. u 5 t. Kyiv: "Radianska shkola". T. 3. S. 53-55. [in Ukrainian]

\title{
FORMATION OF VALUE ORIENTATIONS FOR PRESCHOOL CHILDREN ON THE BASIS OF OF V.O. SUKHOMLYNSKYI'S PEDAGOGICAL HERITAGE: TEACHING EXPERIENCE
}

\author{
Liudmyla Balika \\ Candidate of Pedagogical Sciences, Associate Professor, \\ Associate Professor at the Department of Theory and Methods of Education, \\ Rivne State University for the Humanities, \\ Rivne, Ukraine \\ ORCID: 0000-0003-0042-7744 \\ e-mail: luidmyla.balika@rshu.edu.ua \\ Nina Yaruta \\ educator-methodologist ZDO No $33 \mathrm{~m}$. Rivne, \\ Rivne, Ukraine \\ ORCID: 0000-0003-2705-5725 \\ e-mail: yaruta.nina@gmail.com
}

\begin{abstract}
The importance of the formation of value orientations in preschool children based on the use of V. O. Sukhomlynskyi's pedagogical heritage is substantiated in the article. Attention is focused on creating the best conditions for moral, intellectual, labor, aesthetic development of the child. The experience of the educator-methodologist of preschool education institution No 33 of the town Rivne N. Yaruta, who creatively uses V. O. Sukhomlynsky's heritage in the educating of preschool children, is analyzed.

The leading idea of the educator-methodologist - optimization of the moral experience of the child in the conditions of preschool education, ensuring the relationship of moral knowledge and ideas that children receive in the classroom, with their application in everyday life was defined in the article.

It was found that the formation of value orientations of preschoolers is carried out by the educator through the formation of values to nature, life, the man-made world, man.

To form the value orientations in preschool children she uses the possibilities of classes, clubs, excursions, observations, leisure hours, charity events, work, family holidays, conversations, games etc. Particularly effective are: a series of classes "Child in the natural environment", "Box of good deeds", "Gallery of spirituality", activities with parents, consultations with colleagues, etc. Emphasis is done on the fact that
\end{abstract}


working with the texts of fairy tales, stories of V. Sukhomlynsky', children become more social and more emotional.

It was concluded that N. Yaruta rethinks the content and develops new approaches to the formation of value orientations: through "living" and experiencing the works of V. O. Sukhomlynskyi, helps children discover the world of human relationships, forming a positive perception of the environment and themselves in it; brings children to personal perception and understanding of such philosophical concepts as soul, conscience, goodness, happiness.

Key words: value orientations, preschool children, creative heritage, V. O. Sukhomlynskyi, preschool education institution.

Стаття надійшла до редакиії 08. 10. 2020 р. 